\title{
REALISME MAGIS DALAM CERPEN: \\ KASUS CERPEN GABRIEL GARCIA MARQUEZ, TRIYANTO TRIWIKROMO, DAN A.S. LAKSANA
}

\author{
Imam Muhtarom \\ Alumni Sastra Universitas Airlangga, Surabaya \\ EmailL_imam_muhtarom@yahoo.com
}

\begin{abstract}
Abstrak
Prosa realis magis menghadirkan yang realis dan juga yang magis dalam sebuah cerita. Antara yang realis dan magis berada dalam satu cerita yang saling mendukung. Dukungan antara yang realis dan yang magis ini bukan hanya terwujud dalam kesatuan cerita, tetapi juga memberi kemungkinan untuk memberi pemaknaan yang melampuai kisah itu sendiri. Dalam arti kata, pemaknaan itulah yang memberi pengalaman realis magis bagi pembacanya. Tulisan ini akan memaparkan bentuk realisme magis dalam cerpen karya Gabriel Garcia Marquez berjudul "Light is Like Water", cerpen karya Triyanto Triwikromo berjudul "Sayap Kabut Sultan Ngamid", dan cerpen karya A.S. Laksana berjudul "Dongeng Cinta yang Dungu".
\end{abstract}

Kata kunci: realis, magis, prosa, realisme magis.

\begin{abstract}
Magic Realism Prose brings the magic and the reality at once in a narration. Reality and magic have mutual support to build a narration. The support between the reality and the magic is not only manifested in the unity of the narration but also gives the possibility to give the meaning that goes beyond the narration itself. In other words, the meaning also gives the magic realism experience for the readers. This paper will analyze the form of magic realism in Gabriel Garcia Marquez's short story entitled "Light is Like Water", Triyanto Triwikromo's short story entitled "Sayap Kabut Sultan Ngamid", and A.S. Laksana's short story entitled "Dongeng Cinta yang Dungu".
\end{abstract}

Keywords: real, magic, prose, magic realism.

\section{Pembukaan}

Gagasan penulisan realis-magis telah menjadi gaya yang sudah diterima secara luas oleh para penulis sastra. Gagasan penulisan realis-magis ini berhasil dipopulerkan oleh Gabriel Garcia Marquez lewat karya-karyanya, baik di dalam cerpen maupun novelnya. Karyakarya Marquez mendapat tempat di benak banyak pembaca dan para penulis dari luar Kolumbia, tempat tinggal Marquez.

Dalam tulisan ini akan dipaparkan wujud dari karya cerpen Marquez berjudul "Light is Like Water". Dalam analisis ini dapat dicermati bagaimana gagasan realisme magis mewujud dalam teknik penulisan cerpen maupun gagasan tematiknya.

Selanjutnya, pada analisis karya Triyanto Triwikromo dan A.S. Laksana kita dapat mencermati bagaimana gagasan penulisan realisme magis ini beroperasi di wilayah kultural yang berbeda. Jika Marquez mengkontraskan apa yang terjadi pada Spanyol sebagai penjajah terhadap Amerika Latin, khususnya Kolumbia, maka cerpen "Sayap Kabut Sultan Ngamid" karya Triyanto Triwikromo mengkontraskan Belanda terhadap budaya Jawa. Sementara itu, cerpen A.S. Laksana berjudul "Dongeng Cinta yang Dungu" memaparkan karakter tokoh tidak harus utuh. Karakter tidak dibawa mati sebagaimana pada cerita realis. Karakter dalam konteks kultur di luar budaya Barat bisa berbeda sama sekali dengan adanya manjing ruh, khususnya budaya di Nusantara, ruh yang masuk kepada benda atau mahluk hidup.

Dengan demikian, tulisan ini dapat dibaca sebagai perbandingan karya cerpen, bisa juga dibaca sebagai sebuah metamorfosis gagasan realisme-magis sebagai bentuk penulisan di konteks budaya yang berbeda. Tentu, sekalipun tetap mengusung realisme magis, setiap karya 
tidak lepas dari konteks budayanya masingmasing. Inilah yang justru memperkaya bentuk dari realisme magis itu sendiri.

\section{Realisme Magis dalam Cerpen "Light is Like Water"}

Tokoh Toto dan Joel bersaudara dalam cerpen "Light is Like Water" karya Gabriel Garcia Marquez adalah tokoh anak-anak dengan imajinasi luas yang tak terduga bagi orang dewasa, baik itu kedua orangtuanya, kepala sekolah beserta guru-guru sekolah mereka maupun lingkungan di Jalan Castellana 47 di Cartagena, Madrid, Spanyol. Toto dan Joel bersaudara adalah siswa setingkat SD yang mau giat belajar dan menyabet juara di sekolahnya hanya agar mendapat beragam hadiah, seperti kompas, sextan, perahu, dan alat selam. Hadiah tersebut tak biasa lantaran lingkungan mereka tidak memiliki laut. Toto dan Joel memang tidak menggunakan peralatan tersebut untuk ke laut, tetapi mereka menggunakannya dalam ruang di rumah mereka di apartemen lantai 5.

Anak-anak ini memiliki imajinasi liar yang melampaui benda-benda tak bergerak di rumah mereka. Dalam dunia mereka, bendabenda interior rumah tampak memiliki jiwa. Mereka memperlakukan benda-benda itu sebagai benda-benda hidup yang berbeda pengertiannya dari fungsi keseharian mereka. Benda-benda interior rumah itu tampak berjiwa dan bebas dari kungkungan keseharian dalam pandangan orang dewasa.

Hanya karena tuntutan terus-menerus dari anak-anak, hadiah tak masuk akal dan menjengkelkan orangtuanya, terutama mamanya karena bagi mereka hadiah itu sama sekali tak berguna, akhirnya mereka berikan. Oleh bukti prestasi yang mereka tunjukkan kepada kedua orang tua mereka, daya tawar Toto dan Joel bersaudara kuat di hadapan orangtuanya. Orangtuanya selalu, terutama si ayah, menyediakan peralatan menyelam dan berlayar sebagai hadiah untuk mereka. Bahkan, ketika kedua anak mereka tak minta lagi.

Toto-Joel bersaudara memiliki kehidupan sendiri sebagaimana kedua orangtua mereka juga memiliki kehidupan sendiri. Toto bersaudara intim dengan benda-benda yang mati dalam pandangan orang dewasa tetapi hidup dengan menakjubkan dalam benak mereka. Hal itu dapat dilihat dari kutipan berikut.

"On Wednesday night, as on every Wednesday, the parents went to the movies. The children, masters and lords of the house, closed the doors and windows, and broke the light bulb burning in one of the lamps in the living room. A jet of golden light, as cool as water, began to flow from the broken bulb, and they let it run until it reached a depth of four hand spans. Then they turned off the current, got the boat out, and sailed at their pleasure around the islands of the bouse" (Marquez, 1993).

Cerpen "Light is Like Water" ini tidak menggunakan kata pendukung "dalam pikiran mereka" atau "dalam benak mereka" untuk mengantarkan pembaca ke dalam alam pikiran Toto bersaudara. Cerpen ini langsung menghamparkan kepada pembacanya cahaya meluber yang memenuhi ruang tamu. Dalam luberan cahaya itu, Toto dan Joel naik perahu, berlayar mengelilingi pulau-pulau di dalam rumah mereka. Cahaya menjadi mungkin dalam dunia anak-anak itu sebagaimana halnya air yang dapat menahan beban perahu beserta muatannya. Dunia Toto-Joel bersaudara, demikian juga teman-teman sekelasnya, dunia yang lahir dari dunia keajaiban imajinasi.

Ini berbeda dengan orang tuanya yang sedikit memiliki imajinasi bahkan tidak memiliki daya fantasi untuk membuat mereka menggerakkan kehidupan yang telanjur mekanistis. Semua serba diperhitungkan seperti tampak dari kukuhnya mereka untuk tidak memberi hadiah peralatan selam dan berlayar. Tidak ada imajinasi dalam diri mereka kecuali perhitungan kompensasi berupa benda atas keberhasilan anaknya merebuat juara di sekolah pada setiap kenaikan kelas.

Saking terbatasnya imajinasi orang dewasa ini untuk mengenali bahwa masih ada fantasi dalam dunia ini, mereka harus masuk gedung bioskop untuk menyaksikan fantasi-fantasi yang tidak mereka miliki. Mereka membutuhkan 
sarana lain untuk keluar dari dunia mekanistis yang mengungkung pikiran mereka. Gedung bioskop menjadi pelarian dari situasi mekanistis yang menjadi elemen kehidupan orangorang dewasa. Dalam cerpen ini ditunjukkan orangtua Toto-Joel lebih dari satu kali pergi ke gedung bioskop. Setiap orangtuanya pergi membeli khayalan berupa gambar bergerak di layar bioskop, Toto-Joel justru beraksi dengan fantasi liar mereka.

Orangtua Toto-Joel tiga kali menonton film dan meninggalkan anaknya yang dibanjiri oleh fantasi. Pada kepergian pertama ke gedung bioskop tidak disebutkan judul filmnya, kemudian pada kepergian kedua film yang mereka tonton adalah Last Tango in Paris, sedangkan yang ketiga film The Battle of Argel. Kedua film tersebut merupakan sebuah paradoks dihadapkan dengan peristiwa yang dialami Toto-Joel. Dunia dewasa yang digambarkan dalam film Last Tango in Paris (1972) adalah dunia yang tentu aneh dengan fantasi yang tak kalah anehnya bagi Toto-Joel. Film ini berkisah tentang Paul yang ditinggal mati istrinya lantaran bunuh diri lalu berjumpa dengan Jeanne. Dalam hubungan mereka suatu saat Paul meninggalkan Jeanne begitu saja tanpa pesan. Kemudian mereka bertemu di jalan dan Paul mengatakan ingin hidup bersama dengan Jeanne. Paul mengatakan cinta kepada Jeanne. Jeanne tidak mau. Paul memaksa ke apartemnenya. Jeanne kemudian menembak mati Paul di kamar mandi apartemen itu. Jeanne beralasan merasa hendak diperkosa oleh Paul.

Ketika kedua orangtuanya menonton Last Tango in Paris, Toto bersaudara dalam cerpen ini dikisahkan: "they filled the apartment to the depth of two arm lengths, and they scuba'd around like tame sharks under the furniture and the beds, and they rescued from the depths of the light the things that had been lost in the darkness". Dua peristiwa yang sama sekali berbeda antara dunia anak-anak dan dunia orang dewasa. Toto bersaudara menyelam di dalam cahaya dengan scuba seperti ikan hiu dan menemukan benda-benda yang lama hilang dalam kegelapan.

Betapa rumitnya kehidupan orang dewasa dan aneh sebagaimana dalam Last Tango in Paris. Ada bunuh diri dan pembunuhan lantaran persepsi yang tidak sama. Dunia yang tragis, dan yang lebih tragis lagi, di dalamnya produk imajinasi dalam gambar bergerak itu harus ditonton dengan cara membayar dan duduk bersama-sama terpekur di kursi yang diliputi kegelapan di hadapan layar bioskop yang membentang. Sementara itu, orang juga tahu persis bahwa itu adalah buatan orang juga, dan yang disodorkan bukan fakta melainkan hasil imajinasi. Hanya saja, kenapa demikian menyedihkan imajinasi itu? Orang mengatakan itu sebuah produk kebudayaan modern yang hegemonik lantaran memadukan unsur visual suara yang bergerak, refleksi dunia modern, dan seterusnya. Sebuah dunia yang membeku dan aneh tentunya bagi anak-anak.

Ini berbeda dengan dunia Toto bersaudara. Kegairahan akan kehidupan bukan berasal atau berawal dari objek di luar diri, tetapi berasal dari dalam diri anak-anak itu. Toto bersaudara mampu menghidupkan ruang tamu dan perabotannya menjadi lautan yang bergerak dengan cahaya sebagai airnya. Ia menyelam, bergerak, dan menemukan apaapa yang tersembunyi dan lama tidak dijumpai lagi. Anak-anak tidak memikirkan kenapa tibatiba semua menjadi menarik. Anak-anak tidak mempertanyakan pelbagai kerumitan itu, tetapi girang dengan dunia yang tampak pada mereka. Jika orang dewasa selalu bertanya-tanya apa yang mereka alami, tidak bagi anak-anak seperti Toto-Joel bersaudara. Mereka hanyut dalam dunia penuh ketakjuban itu dan larut bersamanya.

Ketika ayahnya menonton film The Battle of Argel (1966), semakin konkret kontradiksi tersebut. Film yang ditonton orangtua Toto bersaudara berkisah tentang pemberontakan penduduk Aljazair melawan penjajahan Perancis. Film ini sempat dilarang di Perancis dan baru diedarkan di Perancis pada 1971. Sementara kedua orangtuanya menonton film itu, Toto bersaudara mengundang 36 teman sekelasnya untuk berpesta atas keberhasilan mereka mendapat penghargaan sebagai murid 
terpintar. Toto bersaudara sedang berpesta di dalam rumah, tapi warga kota kecil itu melihat cahaya jatuh meluncur dari jendela apartemen Toto-Joel yang tersembunyi di balik pohon. Cahaya itu mengalir deras bagaikan air terjun dan mengalir melintasi kota menuju Sungai Guadarrama.

Ketika para petugas kebakaran kota itu tergopoh-gopoh dengan alat pemadam kebakarannya, mereka justru mendapatkan benda-benda seisi rumah melayang di antara cahaya yang bagaikan air. Hal itu terpapar demikian pada bagian awal paragraf terakhir cerpen Marquez.

"At the end of the hall, floating between two waters, Toto was seated at the stern of the rowboat, glued to the oars, with his scuba mask. on, searching for the lighthouse of the port until bis tanks ran out of air, Joel floated in the prow, still trying to measure the height of the north star with his sextant, and floating throughout the house were his thirty-six classmates, eternally preserved in the instant of peeing in the pot of geraniums, of singing the school song with the verses changed to mock the principal, of sneaking a glass of the dad's brandy" (Marquez, 1993).

Benda-benda menjadi hidup melampaui keberadaan kesehariannya. Benda-benda menjadi demikian indah dan fantastik berserak liar menerobos batas-batas pengertian yang telah baku dalam dunia keseharian.

Karya prosa Gabriel Garcia Marquez di atas memposisikan benda-benda perabotan rumah berubah fungsinya dalam dunia anakanak. Benda itu menampilkan dirinya, menjadi hidup, memiliki jiwa dalam dirinya. Bendabenda yang berinteraksi dengan Joel dan Toto melayang di antara luberan cahaya yang keluar dari bohlam yang mereka pecahkan.

Dalam cerpen 'Light is Like Water", bendabenda dilepaskan dari perspektif lazimnya dalam prosa-prosa realis. Dalam konsepsi Lois Parkinson Zamora (2005: 28), benda-benda dalam prosa Marquez ditampilkan bukan dalam perspektif dunia pandangan tertentu yang lazim dalam prosa realis, tetapi sebaliknya, dari benda-benda itulah sesungguhnya dunia cerpen tersebut dibangun. Benda-benda tidak tertaklukkan oleh tokoh-tokoh sebagai subjek dan agen dalam cerita. Justru, benda-benda itu memiliki kapasitasnya sendiri untuk mandiri dan terpisah dari cengkeraman para tokoh. Bendabenda cerpen Marquez ini melayang di udara, menyembul dari kegelapan, dan mendapatkan wujud yang menakjubkan di mata Joel-Toto beserta teman-teman sekelasnya. Inilah sebuah dunia anak-anak yang belum membuat jarak dan penaklukan atas lingkungan benda-benda di sekitarnya.

Cerpen Marquez berangkat dari apa yang terlihat pada benda-benda, dan dari apa-apa yang terlihat tersebut cerpennya memasuki sesuatu yang tidak terlihat dari dunia keseharian yang menjadi mimesis prosa realis. Dari sinilah bentuk realis magis karya Marquez yang terbangun dalam prosa-prosanya dan secara khusus pada "Light is Like Water".

Visualisasi dalam cerpen Marquez juga menjadi kunci dalam memahami bagaimana benda-benda menjadi hidup dan memiliki jiwa. Prasangka psikologis dalam cerpen Marquez tidak muncul yang biasanya kuat tekanannya pada cerpen-cerpen realis. Benda-benda hadir dalam bahasa yang memberi keutamaan kehadiran benda-benda lebih dari kehadiran tokoh-tokohnya. Kedua orangtua Toto-Joel dalam cerpen ini tak lebih dari sebagai latar belakang belaka. Mereka hadir seperlunya saja untuk membangun kontradiksi antara dunia orang dewasa dan dunia anak-anak beserta benda-benda itu. Dunia orang dewasa yang mekanistis, kering imajinasi dikontraskan dengan dunia anak-anak yang penuh fantasi, magis yang sejajar dengan kehidupan benda-benda itu.

Oleh karena itu, cerpen "Light is Like Water" memiliki kesan kuat dalam aspek visual dan kemampuannya untuk melampaui kebendaannya. Cerpen ini tidak lain dari perwujudan bentangan benda-benda yang hidup dalam keseluruhan cerita. Ia seakan sebuah kanvas yang dibeberkan kepada kita sebagai audiens lewat kerja pembacaan. 


\section{Realisme Magis dalam Cerpen "Sayap Kabut Sultan Ngamid"}

Apa yang visual juga menjadi fokus perhatian cerpen "Sayap Kabut Sultan Ngamid" karya Triyanto Triwikromo (2013: 21-29). Paparan cerpen ini memberi perhatian yang istimewa kepada apa yang visual. Tidak kebetulan bila salah satu topik cerpen ini adalah lukisan 'Penangkapan Pangeran Diponegoro' karya Raden Saleh dan sayap yang mengembang pada bahu Pangeran Diponegoro atau Sultan Ngamid ketika ditangkap secara licik oleh Belanda di Rumah Karesidenan di Magelang pada 28 Maret 1830.

Menjelang penangkapan Pangeran Diponegoro yang dikepalai oleh Jenderal de Kock, muncul sayap-sayap yang tumbuh di bahu Pangeran Diponegoro. Sayap itu mengembang dan mengeluarkan sinar yang menyilaukan di mata Haji Ngisa, penasihat agama Sang Pangeran. Dalam penglihatan Haji Ngisa hal tersebut tampak dalam kutipan berikut.

"Di kedua bahu Sultan tumbuh sayap rajawali ungu yang menyilaukan mata. Sayap-sayap itu seakan tak sabar menerbangkan Sang Junjungan ke langit suci, ke langit sarat sriti. Namun di luar dugaan, Sultan Ngamid menanggalkan bulu-bulu indah yang barangkali diberikan oleh Malaikat Jibril" (Triwikromo, 2013: 22-23).

"Haji Ngisa lebih memilih memandang... ketimbang menatap wajah Sultan Ngamid yang karena terlalu benderang tak lagi bisa dipandang" (Triwikromo, 2013: 23).

Sementara dalam penglihatan Ali Basah Gandakusuma:

"Dia justru melihat Sultan Ngamid mulai memungut sayap rajawali ungu yang semula ditanggalkan. Dengan hati-hati dia mengenakan sayap itu" (Triwikromo, 2013: 25).

"Dia membentangkan tangan dan mengibas-ngibaskan sayap, moksa ke langit, membumbung menembus kabut" (Triwikromo, 2013: 26).
"Gandakusuma melihat sayap rajawali ungu di bahu Sultan Ngamid kian melebar. Sayap itu kian menelan tiang-tiang dan segala yang bisa teraba dan terjamah tangan" (Triwikromo, 2013: 28).

Penglihatan tersebut juga muncul pada Haji Badarudin, panakawan Banthengwareng dan Jayasutra, Pangeran Diponegoro Muda, Raden Mas Joned, dan Raden Mas Raib tapi tidak ditunjukkan dalam cerpen ini. Hanya pada Haji Ngisa dan Ali Basah Gandakusuma sayap tersebut ditunjukkan. Penglihatan itu tidak tampak pada semua prajurit Belanda dan kebanyakan kaum pengikut Pangeran Diponegoro. Bahkan, Jenderal de Kock dibuat tidak tahu pengalaman luar biasa itu agar apa yang sudah menjadi takdir dirinya-Pangeran Diponegoro-ia terima.

Penglihatan pada Ali Basah Gandakusuma dan Haji Ngisa terjadi antara subuh sampai jam 8 pagi sebelum perjumpaan Pangeran Diponegoro atau Sultan Ngamid dengan Jenderal de Kock. Sayap rajawali itu pun juga tidak sama pemaknaannya pada Ali Basah Gandakusuma dan Haji Ngisa. Bagi Haji Ngisa sayap yang muncul di bahu Sang Pangeran adalah pertanda pemberian dari Allah. Sayap itu lambang kedekatan hambanya kepada Allah.

"Haji Ngisa yang telah mengerti betapa kegaiban bisa menghunjam kepada siapa pun yang dipilih Allah hanya mengangguk. Haji Ngisa tak ingin pekikan ketakjuban itu akan mengganggu takdir Allah yang telah ginaris. "Segalanya sudah diatur," desis Haji Ngisa, "bahkan mungkin Jibril pun dititahkan tidur dan tak mencampuri segala yang terjadi dalam silaturahmi indah ini" (Triwikromo, 2013: 23).

Sementara itu, pada Ali Basah Gandakusumo sayap itu memiliki arti lain sama sekali:

"Sayap kematian, pikir dia, sayap yang akan menghentikan perang. Meski demikian, Gandakusumo tidak berani mempertanyakan segala sesuatu yang terkait perang dan kematian" (Triwikromo, 2013: 27). 
Dalam pengertian serupa perwujudan juga bisa tidak sama pada Haji Badarudin, punakawan Banthengwareng dan Jayasutra, Pangeran Diponegoro Muda, Raden Mas Joned, dan Raden Mas Raib. Cerpen ini tidak memberikan informasi mengapa antara Haji Ngisa dan Ali Basah Gandakusuma berbeda pemaknaannya atas sayap pada bahu Pangeran Diponegoro. Cerpen ini hanya memberikan informasi bahwa mereka berdua dan tokohtokoh yang mampu melihat sayap di bahu Sang Pangeran adalah orang-orang terdekatnya, baik sebagai ulama, panglima perang, pengiring atau punakawan, maupun keluarganya.

Penampakan sayap pada bahu Sang Pangeran merupakan sesuatu yang fantastis, magis, dan dalam cerpen ini diperlihatkan kepada orang-orang terdekat Pangeran. Dalam pengertian ini, mereka yang melihat sayap di bahunya adalah orang-orang istimewa. Benda yang tervisualisasi pada sedikit orang dekat Pangeran ini berfungsi sebagai interupsi atas peristiwa penangkapan Sang Pangeran di Rumah Karesidenan di Magelang. Sayap Pangeran yang tampak dalam beberapa orang saja menciptakan visualisasi yang kuat dan memberikan dampak kepada pemaknaan yang tidak realis. Sayap Pangeran memiliki pemaknaan yang fantastik dan magis lantaran sayap itu menyarankan secara kuat kepada hal-hal yang adi-manusiawi.

Sayap dalam cerpen Kabut Sayap Sultan Ngamid karya Triyanto Triwikromo ini sejalan dengan pengertian yang dirumuskan oleh Lois Parkinson Zamora, bahwa magical realism is characterized by its visualizing capacity, that is, its capacity to create (magical) meanings by envisioning ordinary things in extraordinary ways (2005: 31). Sayap yang menyembul dari bahu bukan bermakna sebuah keanehan apalagi kejanggalan yang merusak teks cerpen ini. Sayap itu menjadi sarana untuk membawa teks ini melampaui sifat realisnya dan memaparkan yang magis ke keseluruhan cerpen ini. Sayap yang mengembang melampaui makna verbalnya dan mengantarkan pembaca kepada posisi yang dimiliki Pangeran Diponegoro sebagai puncak pimpinan spiritual sekaligus pimpinan perang selama 1825-1830 dalam melawan kaum kafir yang dimanifestasikan oleh kolaborasi Belanda dan Keraton Yogyakarta.

Sebagai pimpinan spiritual yang dianugerahi kemampuan adi-manusiawi, cerpen ini juga menolak anggapan bahwa Pangeran Diponegoro bukan sebagai korban penipuan yang dilakukan Belanda sebagaimana dijelaskan oleh buku-buku sejarah. Pangeran Diponegoro sesungguhnya sudah tahu apa yang akan terjadi. Sebagai pribadi terpilih oleh Allah, ia telah mengetahui takdir dan ia tidak akan pernah melawan takdir yang telah disematkan padanya. Sebagai pribadi yang menjalani takdir Sang Pangeran bersikap tenang dan menerima apa yang sudah menjadi bagian dari takdirnya.

Ketika Ali Basah Gandakusuma teramat gelisah dengan penangkapan yang sebentar lagi dilakukan Jenderal de Kock bersama prajuritnya, justru sikap tenang yang ditunjukkan Pangeran Diponegoro atau Sultan Ngamid.

"Sudahlah, Gandakusuma," kata Sultan seperti mengerti segala yang dipikirkan oleh panglima utamanya, "pada saat berperang pikirkanlah peperangan. Namun pada saat Lebaran pikirkanlah Lebaran. Ayolah, bersenang-senanglah bersama Jenderal de Kock dan para perwira. Nanti kuberi kuda baru. Nanti kuberi sajadah dan sorban baru. Nanti..." (Triwikromo, 2013: 28).

Pangeran Diponegoro dalam cerpen ini memiliki peluang untuk menggunakannya dengan pergi begitu saja, menghilang, atau bersabda agar Belanda menjadi batu atau terbakar jadi arang atas nama kedekatannya dengan Allah. Namun, Pangeran justru tidak menggunakan kesempatan itu dan seakan menyerah kepada Belanda, padahal ia sedang menjalani takdir yang sudah ditetapkan padanya. Ia tidak mengelak dari takdir sebab takdir telah menetapkan demikian adanya.

Hal itu ditunjukkan sebagaimana kesaksian Haji Ngisa berikut.

"Kalau mau Sultan Ngamid bisa menghilang. Kalau mau segala yang ada 
di Rumah Karesidenan ini bisa dikutuk menjadi batu. Nah, apakah Sampeyan mau dikutuk jadi tengu?" (Triwikromo, 2013: 28).

Ada juga kesaksian Ali Basah Gandakusuma berikut.

"Segalanya sudah diatur oleh Sang Jenderal sialan, tetapi mengapa Sultan percaya bahwa apa pun yang terjadi telah diatur oleh Tuhan dan tak lagi bisa dihindarkan? Desis Gandakusuma dalam kecamuk pikiran tak karuan" (Triwikromo, 2013: 28).

Atas penampakan yang ada pada orang sekelilingnya dan sikap Pangeran Diponegoro yang rela menjalani takdirnya, di bagian penutup cerita ini Raden Saleh sang pelukis "Penangkapan Diponegoro", selaku pencerita memberi tahu perihal alasannya kenapa ia tidak melukis Sultan Ngamid mengenakan sayap rajawali ungu.

Hal ini dikarenakan, katanya:

"Ia akan menanggalkan apa pun yang bukan miliknya. Juga sayap dan kemegahan dunia. Juga sayap dan segala yang dicinta" (Triwikromo, 2013: 29).

"Aku bahagia karena tak menganggap dia sebagai malaikat atau dewa bermata ungu" (Triwikromo, 2013: 29).

Sekalipun dalam cerpen ini diinformasikan tidak adanya sayap dalam kanvas lukisan Raden Saleh, kesan adanya sayap yang tumbuh di bahu Pangeran Diponegoro atau Sultan Ngamid dan kemampuan adi-manusiawinya menguat sepanjang cerita. Alasan Raden Saleh untuk tidak menunjukkan sayap justru memberi terang adanya kekuatan magis di balik kisah Penangkapan Diponegoro sendiri baik tertulis maupun lisan dalam sejarah maupun dalam kita mengamati lukisan 'Penangkapan Pangeran Diponogoro' karya Raden Saleh.

Sayap yang tumbuh di bahu Sultan Ngamid dalam cerpen ini menginterupsi cerita kekalahan Sang Pangeran lantaran penipuan yang dilakukan Belanda. Sebagaimana dalam sastra realis magis, yang magis selalu menginterupsi keberadaan yang realis dan memberi pemaknaan yang melampaui apa-apa yang terjadi secara realis.

Akhirnya, bukan sebagai kekalahan Pangeran Diponegoro tetapi kepatuhan terhadap Tuhan sebagai pemilik makhluk. Peristiwa penangkapan itu toh hanya fakta kecil yang tercatat dalam arsip Belanda sebagaimana dalam penelitian Peter Carey (2013). Akan tetapi, peristiwa tidak sebatas diringkus dalam sejumlah arsip Belanda, tetapi juga yang bisa muncul dalam kemungkinan beragam pengalaman seperti ditampilkan dalam cerpen "Sayap Kabut Sultan Ngamid", khususnya pengalaman dari sudut sumber lokal.

\section{Realisme Magis dalam Cerpen "Dongeng Cinta yang Dungu"}

Apa yang realis magis juga dapat ditemui dalam cerpen "Dongeng Cinta yang Dungu" karya A.S. Laksana (2013: 25-35). Berbeda dengan cerpen Triyanto Triwikromo yang dibahas sebelumnya, cerpen ini tidak menempatkan apa yang magis sebagai sesuatu yang "luar biasa". Dalam cerpen ini, yang menganggap "luar biasa" bisa jadi pihak pembaca, sementara tokoh Fira dan tokoh Abu atau yang disebut tokoh Fira dengan Belatung menjalani kehidupannya tanpa sesuatu yang aneh. Meski demikian, peristiwa itu menimbulkan empati lantaran konsekuensi kehidupan yang harus mereka jalani oleh ketidakpahaman lingkungan sekitarnya dengan apa yang terjadi pada tokoh Fira dan tokoh Belatung.

Dikisahkan Fira sebagai karyawati swasta yang baru masuk di sebuah kantor yang dipimpin oleh si Abu atau Belatung. Fira tidak nyaman di kantor barunya lantaran si Belatung sebagai pimpinan puncak selalu menguntit kemana dia berada. Sebagai bawahan ia tidak mungkin secara terus terang menolak ajakan si bos. Sekalipun di dalam hati ia menolak, tetapi bahasa verbal Fira menyatakan ia setuju oleh ajakan si Belatung. Sampai kemudian si Fira 
jengkel dan memutuskan untuk cuti kerja, lantas sampai pada keputusan untuk mengajukan berhenti kerja begitu cuti kerjanya habis.

Tidak disangka, suatu malam ketika esoknya mau mengajukan cuti kerja, "dirinya" terangkat ke atas menembus atap sebagaimana kutipan berikut.

"Ketika lewat tengah malam, tiba-tiba ia merasa dirinya terangkat pelan-pelan, makin tinggi menembus langit-langit dan atap rumah. Pada saat itu atap rumah tampak bening di matanya sehingga, ketika ia sudah melayang tinggi di atas atap rumahnya, matanya tetap bisa mengamati tubuhnya yang sedang pulas di tempat tidur. Di udara terbuka, Fira seperti capung yang bisa mengambang di tempat dan melesat tiba-tiba, hinggap dari dahan ke dahan dan piknik ke gumpal-gumpal awan" (Laksana, 2013: 28).

Sialnya, ketika "dirinya" lepas dari tubuh, bukannya ia bebas dari Belatung, tetapi di awanawan itu juga ia malah melihat Belatung.

"Sebelum ayam jantan berkokok, datang sesuatu dari arah timur yang mengacaukan pikniknya. Si belatung muncul lagi; ia melayang-layang ke arahnya" (Laksana, 2013: 28-29).

Hingga sampai pada kejadian yang tidak Fira duga sama sekali.

"Ia melihat si belatung menyusup ke dalam tubuhnya. Peristiwa itu terjadi sangat cepat dan Fira tak bisa mencegahnya. Lalu ia melihat tubuhnya menggeliat, membuka mata, dan turun dari tempat tidur. Tubuh yang sekarang berisi Belatung itu melangkah ke cermin, berkaca sebentar membereskan rambutnya yang sedikit awut-autan, dan kemudian keluar kamar menuju ke kamar mandi" (Laksana, 2013: 31).

Fira akhirnya kebingungan lantaran tubuhnya dipakai si Belatung, orang yang sangat ia benci. Lantaran tidak ada tubuh yang menganggur, akhirnya ia masuk ke badan si Belatung.
"Karena tak menemukan siapa pun, akhirnya ia memutuskan masuk ke satusatunya tubuh yang tersedia baginya, yakni tubuh si belatung yang saat itu sedang kosong. Tubuh itu sedang berbaring di tempat tidur, bersebelahan dengan istrinya, seorang perempuan dengan muka mengkilat dan alis seperti kawat yang melengkung tipis sekali" (Laksana, 2013: 32).

Fira dan Belatung terperangkap dalam tubuh yang bukan miliknya. Keduanya berperan dalam tubuh dan situasi sosial yang sama sekali berbeda. Setiap hari Fira memerankan diri sesuai dengan tubuh barunya sebagai atasan. Fira terus merasa rindu pada tubuhnya yang dimasuki oleh si Belatung. Ia juga merasa cemas jangan-jangan si Belatung akan merusak tubuhnya. Dorongan itu membuat Fira untuk selalu bersama tubuhnya.

"Makan siang atau makan malam; menonton bioskop atau sekadar jalanjalan ke mal. Jika tidak ada acara ke mana pun, ia selalu mengantarnya pulang, sekadar memastikan bahwa tubuhnya selamat sampai di rumah. Pernah suatu siang ia begitu kangen kepada tubuhnya dan ingin kembali ke tubuh lamanya itu. Maka dipeluknya tubuh itu dari belakang saat ia sedang bekerja di depan komputer" (Laksana, 2013: 34).

Sampai kemudian terdengar ke telinga si istri Belatung bahwa suaminya serong dengan karyawannya sendiri. Karena istri Belatung adalah anak pemilik dari perusahaan tempat si Belatung menjadi pimpinan utama, disingkirkanlah menantu yang dianggapnya tidak tahu terima kasih ini.

A.S. Laksana mengakhiri ceritanya dengan nada ironis dan datar tanpa berupaya melebih-lebihkan ceritanya yang penuh fantasi dan magis, sebagaimana dalam kutipan berikut.

"Singkat kata, dongeng ini diakhiri dengan kabar bahwa mereka akhirnya menikah dan hidup terlunta-lunta pada mulanya karena setiap orang mencibir perselingkuhan mereka. Namun itu hanya sementara. Selanjutnya nasib mereka 
membaik dan kedunya hidup makmur sebagai sepasang pelawak. Yang lelaki selalu tampil dengan gaya perempuan, yang perempuan selalu bergaya lelaki" (Laksana, 2013: 35).

Tokoh Fira dan tokoh Belatung mengalami peristiwa magis yang mana dalam cerpen ini disebut dengan "dirinya". "Diri" Fira lepas dari tubuhnya seperti air yang keluar dari botol lantas dapat masuk ke dalam botol yang berbeda. Dalam cerpen ini "diri" dipandang sebagai sesuatu bisa lepas sementara badannya bernafas tak bergerak. "Diri" tidak ubahnya kesadaran sewaktu seseorang beraktivitas dengan kemampuan intelektual dan emosionalnya. Ia bisa berpikir dan merasa juga menyimpan segala memori kehidupan masa lalunya serta orientasi masa depannya. Hanya saja, masa kininya terjebak dalam tubuh orang lain.

Cerpen ini tidak mempersoalkan pandangan yang lazim dalam prosa realis bahwa tokoh terbangun atas karakterisasi pada diri seseorang. Tidak pernah terbayangkan bahwa diri yang memiliki riwayat pembentukannya bersama lingkungannya tiba-tiba pindah dalam badan yang lain dan bersemai di dalamnya dengan konsekuensi sosial yang baru pula.

Bisa dibayangkan Fira harus susah payah dalam tubuh barunya tetapi dengan memori yang tetap sebagaimana di badannya yang terdahulu lantaran harus beradaptasi terhadap istri Belatung yang cerewet. Si istri Belatung ini tetap menganggap tubuh suaminya adalah suaminya yang dulu dan bukannya Fira. Kemudian bisa dibayangkan bagaimana Fira harus melatih kebiasaan baru sebagai pimpinan puncak perusahaan, berinteraksi dengan para direksi, berinterakasi dengan mertua Belatung sekaligus pemilik riil perusahaan.

Cerpen ini dengan ringannya sekaligus datar mengisahkan tokoh Fira pindah tubuh seakan tubuh tak ubahnya wadah yang bisa diganti. Cerpen karya A.S. Laksana menerobos batasan yang seakan tak bisa berubah dalam penceritaan realis. Tubuh dan kepribadian adalah sesuatu yang melekat hingga kemudian mati, membusuk dalam liang kubur, dan tulangbelulang menghilang terurai menjadi tanah. Tokoh dalam pengertian realis adalah sesuatu yang absolut dan tak tergantikan. Tokoh Barman dalam novel Khotbah di Atas bukit karya Kuntowijowo selalu konsisten sebagai Barman hingga akhir hidupnya. Tidak dimungkin oleh prosa realis tokoh Barman pindah ke badan tokoh Poppy dan sebaliknya.

Tetapi seperti yang dialami tokoh Fira dan tokoh Belatung ini, kemustahilan itu bisa diterobos dan dengan mudahnya. Cerita yang tidak masuk diakal dalam cerita realis ini ternyata bisa kita nikmati. Lebih dari itu, karya prosa realis magis ini bisa membuat keharuan tersendiri ketika mereka terpojok secara sosial lantaran tuduhan perilaku serong dan selanjutnya memutuskan untuk menjadi pelawak. Si Belatung yang di dalam berisi "diri" Fira memerankan perempuan, sementara si Fira yang berisi “diri” Belatung memerankan laki-laki. Ironi ini kian membekas bahwa sesungguhnya karakter perempuan yang dilihat penonton bukanlah dramatisasi tetapi demikianlah adanya si Fira di dalam tubuh si lelaki. Demikian sebaliknya yang menimpa pada tokoh Belatung yang berada di dalam tubuh perempuan.

\section{Kesimpulan}

Ketiga cerpen karya Gabriel Garcia Marquez, Triyanto Triwikromo, dan A.S. Laksana memberikan pengalaman pembacaan cerpen-cerpen yang mengambil bentuk realisme magis. Realisme magis dalam ketiga penulis prosa tersebut terdapat pada objekobjek yang memberikan kapasitas pemaknaan yang melampaui yang realis. Objek-objek pada cerpen "Light is Like Water" karya Marquez menjadi sarana untuk masuk ke dalam dunia magis anak-anak yang tidak ditemui pada dunia orang-orang dewasa. Sementara itu, cerpen "Sayap Kabut Sultan Ngamid" karya Triyanto Triwikromo menghadirkan sayap yang menyembul dari bahu Pangeran Diponegoro yang menjadi penanda ke dalam pemaknaan 
yang melampaui realis dan masuk ke dalam pemahaman spiritual yang lebih dalam. Pada cerpen "Dongeng Cinta yang Dungu" karya A.S. Laksana, yang realis magis ada pada pertukaran "diri" tokoh Fira dan tokoh Belatung ke badan mereka. Pertukaran dan perpindahan "diri" menyarankan pada pengalaman yang melampuai batas kemungkinan dari pemahaman realis.

\section{Daftar Pustaka}

Carey, Peter. Kuasa Ramalan. 2013. Penerjemah: Parakitri T. Simbolon. Jakarta: Kepustakaan Populer Gramedia.

Hart, Stephen M. dan Wen-Chin Ouyang, A Companion to Magical Realism, 2005, New York: Tamesis.

Laksana, A.S.. 2013. Murjangkung, cintayang dungu dan hantu-hantu. Jakarta: GagasMedia.

Marquez, Gabriel Garcia. "Light is Like Water." Strange Pilgrims. 1993. Trans by Edith Grossman. New York: Alfred A. Knopf, Inc.

Triwikromo, Triyanto. 2013. Celeng Satu Celeng Semua. Jakarta: Gramedia Pustaka Utama.

\section{Pustaka online:}

http://www.ejumpcut.org/archive/onlinessays/ JC04folder/LastTango.html diunduh pada pukul 11.30 pada 28 Maret 2014 bttp: / / nymag.com / nymetro / movies / reviews/n_9697/ diunduh pukul 12.30 pada 28

Maret 2014 